\title{
IDENTIFIKASI PERMASALAHAN-PERMASALAHAN DALAM PEMBELAJARAN IPS
}

\author{
${ }^{1}$ B. Fitri Rahmawati, ${ }^{2}$ Zidni \\ ${ }^{1,2}$ Universitas Hamzanwadi \\ fitri.fkiphamzanwadi@gmail.com, zidnipancorkopong@gmail.com
}

\begin{abstract}
Abstrak
Mata pelajaran IPS merupakan salah satu mata pelajaran yang dibelajarkan secara terintegarasi di tingkat SMP. Pembelajaran terintegrasi ini menimbulkan persoalan tersendiri dalam pembelajaran IPS. Tujuan dari penelitian ini adalah untuk mengidentifikasi permasalahan-permasalahan dalam pembelajaran IPS. Metode yang digunakan adalah metode kualitatif. Informan yang digunakan adalah guru-guru dan siswa dari tujuh sekolah SMP/MTs. Metode pengumpulan data adalah wawancara, observasi dan dokumentasi. Analisis data menggunakan analisis deskriptif. Berdasarkan hasil penelitian, dapat diidentifikasi empat permasalahan yakni perilaku disruptif siswa, kurangnya sarana dan prasarana pembelajaran, guru kurang memahami materi di luar bidang ilmunya serta metode pembelajaran yang kurang variatif. Perilaku disruptif siswa yang teridentifikasi adalah berkeliaran dan bermain-main ketika pembelajaran berlangsung, susah diatur, tidak mengerjakan tugas yang diberikan, membuat keributan di dalam kelas, tidak memperhatikan, dan mengantuk. Sedangkan sarana-dan prasarana pembelajaran yang dianggap masih kurang adalah buku dan media pembelajaran. Guru juga merasa kesulitan dalam memahami materi pelajaran di luar bidangnya dan metode pembelajaran yang digunakan kurang variatif karena lebih banyak menggunakan metode ceramah.
\end{abstract}

Kata Kunci: Identifikasi, Studi Sosial, Permasalahan.

\begin{abstract}
Social studies are one of the subjects that are taught in an integrated approach at the junior high level. This integrated learning raises its own problems in social studies learning. The purpose of this study is to identify problems in sociall studies learning. The method used is a qualitative method. The informants used were teachers and students from seven SMP/MTs. Data collection methods are interviews, observation and documentation. Data analysis uses descriptive analysis. Based on the results of the study, four problems can be identified namely students' disruptive behavior, lack of learning facilities and infrastructure, teachers lack understanding of material outside their field of learning and less varied learning methods. The disruptive behavior of students identified is wandering and playing when learning takes place, is difficult to manage, does not do the assignments, makes noise in class, does not pay attention, is sleepy, and talks. While learning facilities and infrastructure which are considered still lacking are books and learning media. The teacher also feels difficulty in understanding subject matter outside his field and the learning methods used are less varied because they use the lecture method more.
\end{abstract}

Keyword: Identification, Social Studies, Problem 


\section{PENDAHULUAN}

Tuntutan kebutuhan masyarakat terus berubah seiring perkembangan ilmu pengetahuan dan teknologi. Belum terjawab tantangan dari era industri 4.0, muncul lagi konsep baru yaitu society 5.0. Hal tersebut memberikan gambaran bahwa perubahanperubahan ke arah yang lebih baik menjadi sesuatu yang niscaya untuk dilakukan. Perubahan kurikulum di Indonesia menjadi salah satu wujud dari keniscayaan perubahan untuk menjawab tuntutan masyarakat yang terus berubah. Diterapkannya Kurikulum 2013 dilandasi oleh timbulnya permasalahan-permasalahan yang muncul pada penerapan kurikulum sebelumnya mulai dari isi, kompetensi, proses, sampai masalah penilaian (Anwar, 2014).

Inti dari Kurikulum 2013 adalah penyederhanaan sehingga muatan kurikulum disajikan secara tematik-integratif pada Sekolah Dasar (SD) dan Sekolah Menengah Pertama (SMP). Pembelajaran integratif adalah pendekatan pembelajaran yang memadukan berbagai disiplin ilmu menjadi satu. Menurut Fogarty (1991), pembelajaran integratif merupakan bentuk kurikulum yang memadukan baik materi, pengalaman belajar, dan keterampilan, tema, konsep dan topik dari berbagai disiplin ilmu. Integrasi ini dapat dilakukan dalam bentuk intradisipliner maupun interdisipliner. Sedangkan menurut Drake (2007) pembelajaran terpadu dibagi menjadi tiga jenis yaitu interdisipliner, multidisipliner dan transdisipliner.

Pendekatan terpadu dapat memberikan pengalaman belajar yang bermakna karena sesuai dengan kebutuhan peserta didik (Hermawan, 2014). Pembelajaran terpadu memberikan ruang bagi peserta didik untuk membangun konsep dari berbagai peristiwa dan informasi yang saling berkaitan sehingga dapat memahami masalah-masalah kompleks yang ada dilingkungan sekitarnya. Kohler menyatakan bahwa pembelajaran akan berhasil jika peserta didik mampu memadukan semua unsur dan menempatkannya dalam satu cara untuk memecahkan masalah secara utuh. Solusi akan muncul jika seseorang mampu menggunakan keseluruhan stimulus yang ada di sekitarnya sehingga terbentuklah sebuah wawasan (Hergenhahn \& Olson, 2008). Adapun konsep pembelajaran terpadu menurut Kemendikbud (2013c) adalah pendekatan pembelajaran yang mengintegrasikan berbagai kompetensi dari berbagai mata pelajaran ke dalam berbagai tema.

Berdasarkan konsep tersebut di atas, Sa'ud (Saud, 2006) menyatakan bahwa pembelajaran terpadu harus dilaksanakan sesuai prinsip-prinsip sebagai berikut: 1) The hidden curriculum, pembelajaran tidak terpaku pada satu pokok permasalah tertentu 
sehingga pembelajaran akan menjadi penuh makna bagi anak; 2) Subject in the curriculum, pembelajaran harus benar-benar dilaksanakan dengan mempertimbangkan pemilihan materi pokok belajar, waktu belajar, dan penilain kemajuan belajar; 3) The learning environment, lingkungan belajar yang memberikan peluang bagi peserta didik untuk mengembangkan potensinya; 4) Views of social world, pembelajaran harus didasarkan pada kehidupan dan kebutuhan masyarakat; dan 5) Value and attitude, pembelajaran diarahkan pada pembentukan nilai pada diri peserta didik.

Salah satu mata pelajaran yang disajikan secara terintegrasi adalah mata pelajaran Ilmu Pengetahuan Sosial (IPS). Dalam konteks pendidikan barat, IPS dikenal sebagai social studies yang didefinisikan Edgar B. Wesley sebagai ilmu sosial yang disederhanakan untuk tujuan pedagogis (Zevin, 2013). Untuk IPS yang diajarkan di sekolah menengah, Zevin mendefiknisikan sebagai studi data, analisis, dan masalah etika yang berhubungan dengan sejarah manusia, perilaku manusia, dan nilai-nilai manusia. Singkatnya, studi sosial di kelas adalah tentang bagaimana dan mengapa orang bertindak, apa yang mereka yakini, dan di mana dan bagaimana mereka hidup dan telah hidup. Ini tentang aksi, ide, nilai, waktu, dan tempat (serangkaian topik) yang mencakup rentang yang sangat luas dan agak tidak berbentuk, tetapi memungkinkan kebebasan yang luar biasa dalam pemilihan bahan dan metode untuk guru (Zevin, 2013).

Pendekatan pembelajaran terpadu dalam IPS sering disebut dengan pendekatan interdisipliner (Winataputra \& Darojat, 2014). Beberapa model penerapan pendekatan terpadu dalam pembelajaran IPS menurut Depdiknas (2007b) dapat dikategorikan sebagai berikut: 1) model integrasi berdasarkan topic, misalnya tema kegiatan ekonomi penduduk ditinjau dari geografi, ekonomi, sosiologi dan sejarah; 2) model integrasi berdasarkan potensi utama wilayah setempat misalnya "potensi Lombok sebagai daerah wisata Budaya" dapat dikaji dari faktor alam, historis dan budaya masyarakat setempat; 3) model Integrasi berdasarkan permasalahan yang ada, misalnya tentang TKI ditinjau dari segi geografi, ekonomi, sosiologi dan historis; 4) model integrasi lintas disiplin ilmu yang merupakan model yang digunakan di sekolah dasar. Dengan pembelajaran terpadu, siswa dapat mencapai kompetensinya secara utuh baik itu pengetahuan, sikap dan keterampilan.

Kompleksitas materi dan banyaknya alternative model yang dapat dikembangkan dapat menimbulkan kendala bagi guru karena sulitnya menemukan bentuk dan model yang tepat untuk pembelajaran IPS. Menurut Ucar (Úcar, 2013) bahwa kompleksitas pendidikan sosial dapat menimbulkan beberapa kendala yakni : (1) 
the cognitive missunderstanding yakni mengenai bagaimana mempersiapkan proses pembelajaran dan isi materi yang akan dibelajarkan; (2) the political trap, yaitu terkait dengan tujuan dan fungsi sosial; (3) the misunderstanding of scientificity, yang mengacu pada konseptualisasi disiplin; (4) the misunderstanding of action, terkait dengan keragaman pendekatan yang digunakan dan kesulitan menilai hasil dari tindakan; (5) the misunderstanding of normativeness, yaitu terkait dengan tindakan profesional dan hasilnya; dan (6) the misunderstanding of the social, yang mengacu pada inti dan batasan pedagogi sosial. Lebih lanjut menurut Ucar (Úcar, 2013) bahwa kenam kesalahpahaman ini telah memengaruhi konseptualisasi disiplin atau praktik profesionalnya.

Berdasarkan hasil penelitian Asarina (Asarina, 2014) bahwa guru masih menghadapi beberapa kendala dalam pembelajaran IPS yakni pada aspek perencanaan, implementasi dan evaluasi pembelajaran. Pada tahap perencanaan pembelajaran, guru menghadapi kendala yakni kesulitan memadukan materi, kurangnya buku pedoman, belum mampu membuat tema atau topic pembelajaran, sulit menjabarkan KD, dan sulit mengalokasikan waktu baik untuk menyusun perangkat pembelajaran maupun untuk kegiatan pembelajaran. Pada tahap implementasi pembelajaran, guru juga menemukan kendala yakni tidak semua siswa siap untuk mengikuti pembelajaran IPS, guru kurang memahami keseluruhan materi IPS karena latar belakang keilmuan yang terspesialisisi, waktu yang terbatas, dan belum mampu menerapkan metode yang bervariasi. Sedangkan dalam evaluasi pembelajaran, sulitnya menyusun instrument penilaian menjadi kendala bagi guru.

Kondisi-kondisi tersebut di atas menunjukkan bahwa perbaikan-perbaikan dalam berbagai tahap dalam pembelajaran IPS mutlak diperlukan. Efektivitas dari upaya yang dilakukan salah satunya dapat diupayakan dengan menyesuaikan upaya dengan kebutuhan. Oleh karena itu, penelitian ini dimaksudkan untuk mengidentifikasi permasalahan-permasalahan pembelajaran IPS di beberapa sekolah di Lombok Timur. Hasil penelitian ini dapat dijadikan sebagai dasar dalam menemukan solusi yang dapat dikembangkan untuk efektivitas dan kualitas pembelajaran IPS.

\section{METODE PENELITIAN}

Penelitian ini menggunakan penelitian kualitatif deskriptif karena bertujuan untuk mengidentifikasi permasalahan-permasalahan pembelajaran IPS. Informan dalam penelitian ini adalah guru IPS dan siswa dari tujuh sekolah SMP/MTs yakni MTs 
Mu'allimin NW Pancor, MTs. Arra'ufiyah, SMP Islam Arra'ufiyah, SMP Al-Gufron Tete Batu, SMP Laboratorium Hamzanwadi, MTs. NW Korleko dan MTs. Mu'allimat NW Pancor. Adapun teknik pengumpulan data dalam penelitian ini adalah wawancara, observasi dan dokumentasi. Teknik analisis yang digunakan adalah teknik analisis deskriptif.

\section{HASIL PENELITIAN DAN PEMBAHASAN}

Pembelajaran IPS merupakan salah satu bentuk pembelajaran integrative yang terapkan di SMP. Adanya pengintegrasian beberapa disiplin ilmu ke dalam satu mata pelajaran memberikan kendala bagi guru IPS. Berdasarkan hasil wawancara yang dilakukan dengan beberapa guru IPS dari tujuh sekolah yang berbeda menunjukan bahwa permasalahan pembelajaran IPS dapat dikelompokkan menjadi:

\section{Perilaku Disruptif Siswa}

Perilaku disruptif siswa atau yang dikenal dengan istilah Disruptive Classroom Behaviors (DCB) (Wicaksono, 2012) adalah perilaku tampak yang terjadi di dalam kelas yang menganggu guru dan atau siswa yang lain, contohnya yaitu menolak berpartisipasi atau bekerjasama dalam kegiatan kelas, mengabaikan hak orang lain, tidak memperhatikan pelajaran, membuat keributan dan meninggalkan tempat duduk tanpa ijin (Bidell \& Deacon, 2010). Dari perspektif guru, hasil wawancara menunjukkan bahwa dalam kegiatan pembelajaran IPS di kelas, masih banyak siswa yang menunjukkan perilaku yang mengganggu kegiatan pembelajaran, misalnya berkeliaran dan bermain-main ketika pembelajaran berlangsung, susah diatur, tidak mengerjakan tugas yang diberikan, membuat keributan di dalam kelas, tidak memperhatikan, mengantuk, dan ngerumpi.

Salah seorang guru MTs. menyatakan: "sulit membuat siswa saya tenang pada saat belajar, makanya selalu ribut, yang laki-laki main kejar-kejaran, yang perempuan ngerumpi, mungkin karena mereka baru kelas 1 jadi suasana SD nya masih terbawa”. Guru salah satu SMP juga menyatakan hal yang senada "kendala yang saya hadapi dalam pembelajaran IPS itu terutama masalah siswanya, banyak yang tidak memperhatikan, ada juga yang bandel, kalau diminta mencatat mereka malas dan diminta memfoto kopy buku juga ada saja yang tidak mau”. Dengan redaksi yang berbeda, salah satu guru juga menyampaikan bahwa kendala yang dihadapinya dalam pembelajaran IPS adalah motivasi siswa yang kurang, siswa lebih banyak ribut untuk hal-hal di luar proses pembelajaran tetapi kurang aktif dalam kegiatan diskusi. 
Jika dilihat dari sudut pandang siswa, kondisi ini disebabkan karena kurangnya minat siswa dalam pembelajaran IPS. Menurut beberapa siswa, metode yang digunakan oleh guru menjadi salah satu penyebabnya. Guru IPS lebih banyak menggunakan metode ceramah yang membuat siswa bosan dan mengantuk, terlebih lagi pelajaran IPS ditempatkan pada jam terakhir. Siswa lainnya menyatakan bahwa guru lebih banyak memarahi siswa dari pada memberikan motivasi. Selain itu, tugas mencatat yang diberikan oleh guru seringkali terlalu banyak sehingga siswa menjadi malas untuk menyelesaikannya.

\section{Kurangnya Sarana Dan Prasarana Pembelajaran}

Selain faktor siswa, kurangnya sarana dan prasarana pembelajaran seperti buku, media pembelajaran, dan laboratorium juga menjadi kendala yang dihadapi dalam pembelajaran IPS. Di beberapa sekolah, buku yang dimiliki sebagai sumber belajar masih minim terutama buku pegangan siswa. Buku yang dimiliki siswa tidak sesuai dengan jumlah siswa, akibatnya satu buku digunakan oleh dua siswa bahkan lebih. Oleh karena itu, pada beberapa kondisi, guru terpaksa memberikan tugas mencatat kepada siswa. Kondisi ini juga menyebabkan guru lebih memilih menggunakan metode ceramah dibandingkan dengan metode-metode lainnya. Seperti yang dinyatakan oleh salah seorang guru yakni "kita disini kekurangan buku, makanya satu buku biasanya digunakan oleh dua atau lebih siswa". guru lainnya menyatakan: "karena buku sangat kurang makanya saya menggunakan ceramah, ya mau bagaimana lagi, kalaupun kita minta siswa untuk diskusi kan paling tidak mereka harus punya buku”.

Kondisi ini juga dikeluhkan oleh siswa sendiri. Kurangnya buku mengharuskan mereka berbagi dengan teman lainnya. Akibatnya, siswa menjadi kurang antusias dalam mengikuti pelajaran IPS. Menurut salah satu siswa, hal tersebut menyebabkan dirinya dan teman-teman lainnya melakukan hal-hal di luar kegiatan belajar seperti memukul meja atau mengganggu teman-temannya. Salah seorang siswa menyatakan: "ga ada buku soalnya, kita mau ikut membaca, ga kebagian bukunya, jadinya males". Siswa lainnya juga menyatakan hal senada:"mau ikut belajar bukunya ga ada, satu kelompok paling dikasi cuma satu buku”.

Pemanfaatan media pembelajaran sangat penting untuk meningkatkan aktivitas dan hasil belajar siswa. seperti yang dinyatakan Arsyad bahwa proses pembelajaran tersebut dapat lebih dinamis dan akan mencapai sasaran yang diinginkan jka ditambahkan alat bantu atau media lain, seperti media audio visual, cetak, proyektor, film, permainan dan lain sebagainya (Arsyad, 2013). Lebih lanjut Arsyad memaparkan 
manfaat dari penggunaan media yakni 1) Pembelajaran lebih menarik perhatian peserta didik sehingga dapat menumbuhkan motivasi belajar; 2) Pembelajaran menjadi lebih jelas dan bermakna, sehingga dapat dipahami oleh peserta didik, 3) Peserta didik dalam kegiatan belajar tidak hanya menyimak uraian guru saja, tetapi juga aktivitas lain seperti mengamati, melakukan, memerankan, dan mendemonstrasikan, dan 4) Model atau metode mengajar akan lebih bervariasi, tidak hanya komunikasi verbal atau ceramah saja oleh guru, sehingga peserta didik tidak merasa jenuh, bosan, dan guru tidak kehabisan tenaga (Arsyad, 2014). Hasil penelitian Mayasari (Mayasari, 2019) juga menunjukkan bahwa Model pembelajaran Value Clarification Technique (VCT) berbantuan media memberi pengalaman nyata, menstimulasi berfikir siswa untuk kreatif, berpusat pada peserta didik, dan membuat makna dalam kehidupan. Penggunaan media audio visual juga meningkatkan kualitas belajar mengajar dan mengurangi verbalisme sehingga melalui media pembelajaran guru dapat lebih mengefektifkan pencapaian tujuan pembelajaran.

Berbagai jenis media dapat dimanfaatkan dalam pembelajaran IPS misalnya media ular tangga (Afandi, 2015), CD interaktif (Herijanto, 2012), dan media berbasis web (Uno \& Ma'ruf, 2016). Rahmatullah menunjukkan bahwa pembelajaran dengan memanfaatkan media film animasi menunjukkan peningkatan motivasi dan minat belajar serta lebih mudah dalam memahami konsep-konsep IPS yang diajarkan (Rahmatullah, 2011). Media video juga efektif untuk memudahkan anak memahami materi, dan menimbulkan semangat dan antusias sehingga dapat meminimalisir rasa ngantuk dan bosan pada siswa (Putri, 2012). Media pembelajaran dapat disesuaikan dengan situasi dan kondisi pembelajaran.

\section{Kesulitan Memahami Materi Diluar Bidang Ilmu}

Mata pelajaran IPS yang disajikan secara terintegrasi dengan menggabungkan geografi, sejarah, ekonomi dan sosiologi memberikan kesulitan tersendiri bagi guru. Guru yang berlatar belakang pendidikan sejarah merasa sulit dalam mengajar materi selain sejarah, demikian juga guru yang berlatar belakang pendidikan geografi, ekonomi dan sosiologi merasa kesulitan ketika menyampaikan materi diluar bidang ilmunya. Sebagian besar guru mengalami hal yang sama ketika harus menyampaikan materi di luar bidang ilmunya. Seperti yang dinyatakan salah seorang guru: "saya kadang menemukan kesulitan ketika akan menyampaikan materi di luar bidang saya. Walaupun dulu pernah juga kita diajarkan tetapi tidak terlalu mendalam”. 
Menguasai materi pelajaran merupakan salah satu kompetensi guru yakni kompetensi profesional. Menurut Undang-undang Nomor 14 tahun 2005 tentang Guru dan Dosen, kompetensi profesional adalah "kemampuan penguasaan materi pelajaran secara luas dan mendalam" (Nuraida, 2013). Jika guru tidak menguasai materi pelajaran, maka akan berdampak pula pada kurangnya pemahaman siswa, karena kompetensi professional guru memberikan pengaruh yang signifikan terhadap prestasi belajar siswa (Sulistyowati, Sukardi, \& Sukardi, 2012; Wulandari, 2013) dan motivasi belajar siswa (Widoyoko \& Rinawat, 2012).

\section{Metode Pembelajaran Yang Kurang Variatif}

Hasil wawancara menunjukkan bahwa metode yang bahwa metode yang paling sering digunakan dalam pembelajaran IPS adalah metode ceramah. Salah seorang guru menyatakan:" metode yang paling sering saya gunakan adalah metode ceramah karena kurangnya buku. Kalau menggunakan metode yang lain seperti diskusi kan siswa harus memiliki buku untuk dibaca biar ada bahannya untuk diskusi”. Hal senada juga dinyatakan siswa:" guru hanya ceramah, makanya kami cepat ngantuk dan bosan".

Seperti yang dinyatakan guru tersebut, guru kesulitan dalam memberikan variasi pada metode pembelajaran karena kurangnya fasilitas belajar. Buku yang dimiliki masih kurang dan masih belum optimalnya kreativitas guru dalam mengembangkan media pembelajaran. Penggunaan metode yang kurang bervariasi akan menyebabkan siswa menjadi bosan, mengantuk, kurang termotivasi yang akan berdampak pada hasil belajarnya. Disamping itu, metode ceramah lebih menekankan pada pembelajaran yang berpusat pada guru, kondisi yang sangat kontras dengan idealitas pembelajaran saat ini.

Paradigma pembelajaran yang sudah berubah dari teacher centered menjadi student centered menuntut guru untuk dapat menyiapkan kondisi dimana siswa yang lebih aktif dalam pembelajaran. Dalam kurikulum 2013 pun juga menegaskan untuk diterapkannya berbagai model pembelajaran yang berbasis saintifik, inquiry, tematik dan berbasis masalah dan berbasis proyek. Selain itu, terdapat banyak model dan metode pembelajaran yang dapat dijadikan alternative sebagai variasi dalam pembelajaran IPS yakni Contextual Teaching and Learning (CTL), kooperatif, konstruktivisme dan lain-lain. Menurut Perwitasari pendekatan saintifik dipandang sebagai pembelajaran yang mengaktifkan siswa agar dapat membangun pengetahuannya dengan langkah-langkah ilmiah yaitu mengamati, menanya, mengumpulkan informasi, mengasosiasi, dan mengomunikasikan guru hanya sebagai fasilitator dan pendamping (Perwitasari, 2016). Sementara itu, penggunaan model pembelajaran Contextual 
Teaching and Learning (CTL) memberikan pengalaman nyata, berfikir tingkat tinggi, berpusat pada peserta didik, kritis dan kreatif, pengetahuan bermakna dalam kehidupan, dekat dengan kehidupan nyata, adanya perubahan prilaku, pengetahuan. Selain itu hasil belajar peserta didik dapat meningkat (Sulfemi, 2019).

\section{KESIMPULAN}

Permasalahan-permasalahan yang dapat diidentifikasi dalam pembelajaran IPS adalah perilaku disruptif siswa, kurangnya sarana dan prasarana pembelajaran, guru kurang memahami materi di luar bidang ilmunya, dan metode pembelajaran yang kurang variatif. Perilaku disruptif siswa yang teridentifikasi adalah berkeliaran dan bermain-main ketika pembelajaran berlangsung, susah diatur, tidak mengerjakan tugas yang diberikan, membuat keributan di dalam kelas, tidak memperhatikan, mengantuk, dan ngerumpi. Sedangkan sarana-dan prasarana pembelajaran yang dianggap masih kurang adalah buku dan media pembelajaran. Guru juga merasa kesulitan dalam memahami materi pelajaran di luar bidangnya dan metode pembelajaran yang digunakan kurang variatif karena lebih banyak menggunakan metode ceramah.

\section{DAFTAR PUSTAKA}

Afandi, R. (2015). Pengembangan media pembelajaran permainan ular tangga untuk meningkatkan motivasi belajar siswa dan hasil belajar IPS di sekolah dasar. JINoP (Jurnal Inovasi Pembelajaran), 1(1), 77-89.

Anwar, R. (2014). Hal-hal yang mendasari penerapan Kurikulum 2013. Humaniora, 5(1), 97-106.

Arsyad, A. (2013). Media Pembelajaran; Edisi Revisi.

Arsyad, A. (2014). Media Pembelajaran (edisi ke-17). Jakarta: PT. Raja Grafindo Persada.

Asarina, R. (2014). Studi Eksplorasi Kendala-Kendala Guru dalam Pembelajaran IPS di SMP Wilayah Kecamatan Moyudan. Yogyakarta: Universitas Negeri Yogyakarta.

Bidell, M. P., \& Deacon, R. E. (2010). School Counselors Connecting the Dots between Disruptive Classroom Behavior and Youth Self-Concept. Journal of School Counseling, 8(9), n9.

Dudung, A. (2018). KOMPETENSI PROFESIONAL GURU. JKKP (Jurnal Kesejahteraan Keluarga Dan Pendidikan), 5(1), 9-19.

Hergenhahn, B. R., \& Olson, M. H. (2008). Theories of Learning (teori belajar). Tri Wibowo BS (Alih Bahasa). Jakarta: Kencana Prenada Media Group.

Herijanto, B. (2012). Pengembangan CD Interaktif Pembelajaran IPS Materi Bencana Alam. Journal of Educational Social Studies, 1(1).

Hermawan, A. H. (2014). Konsep Dasar dan Model-model Pembelajaran Terpadu. Diakses Dari Http://Www. Repository. Ut. Ac. Id/4039/1/PDGK4205-M1. Pdf.[20 Juli 2018]. 
Mayasari, N. (2019). Peranan Model Pembelajaran Value Clarification Technique Berbantuan Media Audio Visual Untuk Meningkatkan Hasil Belajar IPS. Jurnal Pendidikan, 20(1), 53-68.

Nuraida, N. (2013). Kompetensi profesional guru untuk meningkatkan mutu pembelajaran di Madrasah Ibtidaiyah Negeri Sei Agul Medan. Pascasarjana UIN Sumatera Utara.

Perwitasari, A. A. (2016). Penerapan Pendekatan Saintifik dalam Pembelajaran IPS di SMP Negeri 15 Yogyakarta. SOCIAL STUDIES, 5(3).

Putri, N. (2012). Efektifitas penggunaan media video untuk meningkatkan pengenalan alat musik daerah pada pembelajaran IPS bagi anak tunagrahita ringan di SDLB 20 kota solok. Jurnal Ilmiah Pendidikan Khusus, 1(2), 318-328.

Rahmatullah, M. (2011). Pengaruh pemanfaatan media pembelajaran film animasi terhadap hasil belajar. Jurnal Penelitian Pendidikan, 12(1), 178-186.

Saud, U. S. (2006). dkk. 2006. Pembelajaran Terpadu. UPI Press. Bandung.

Sulfemi, W. B. (2019). Model Pembelajaran Contextual Teaching And Learning (CTL) Berbantu Media Miniatur Lingkungan Untuk Meningkatkan Hasil Belajar IPS. Edunomic: Jurnal Ilmiah Pendidikan Ekonomi Fakultas Keguruan Dan Ilmu Pendidikan, 7(2), 73-84.

Sulistyowati, Y., Sukardi, W. W., \& Sukardi, F. X. S. F. X. (2012). Pengaruh Motivasi Belajar dan Kompetensi Profesional Guru terhadap Prestasi Belajar Mata Pelajaran IPS Ekonomi Siswa Kelas VII SMP Negeri 3 Magelang Tahun Pelajaran 2011/2012. Economic Education Analysis Journal, 1(2).

Úcar, X. (2013). Exploring different perspectives of Social Pedagogy: towards a complex and integrated approach. Education Policy Analysis Archives, 21(36), n36.

Uno, H. B., \& Ma'ruf, A. R. K. (2016). Pengembangan Media Pembelajaran IPS Berbasis Website untuk Siswa Kelas VII Madrasah Tsanawiyah Negeri. JTPJurnal Teknologi Pendidikan, 18(3), 169-185.

Wicaksono, T. H. (2012). Perilaku Mengganggu Di Kelas. Paradigma, 7(14).

Widoyoko, S. E. P., \& Rinawat, A. (2012). Pengaruh kinerja guru terhadap motivasi belajar siswa. Jurnal Cakrawala Pendidikan, 5(2).

Winataputra, U. S., \& Darojat, O. (2014). Materi dan pembelajaran IPS SD.

Wulandari, D. (2013). Pengaruh kompetensi pedagogik dan kompetensi profesional guru terhadap economic literacy melalui prestasi belajar siswa kelas XII IPS di SMA Kota Malang. Jurnal Pendidikan Humaniora, 1(1), 25-29.

Zevin, J. (2013). Social studies for the twenty-first century: Methods and materials for teaching in middle and secondary schools. Routledge. 